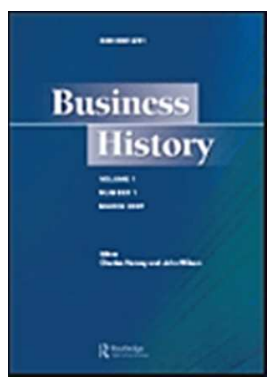

\title{
Extending William Baumol's theory on entrepreneurship and institutions: lessons from post-Second World War Greece
}

\begin{tabular}{|r|l|}
\hline Journal: & Business History \\
\hline Manuscript ID & FBSH-2017-0106.R1 \\
\hline Manuscript Type: & Original Article \\
\hline Keywords: & Entrepreneurship, William Baumol, Institutions, Tax System, Greece \\
\hline \multicolumn{2}{|l}{} \\
\end{tabular}

\section{SCHOLARONE}

Manuscripts 


\title{
Extending William Baumol's theory on entrepreneurship and institutions: lessons from post-Second World War Greece
}

\begin{abstract}
This article examines William Baumol's theory about the interaction between taxation and entrepreneurship and proposes an extension to it. The analysis shows that the traditional form of Baumol's model, focusing mainly on the level of taxes, cannot be used in order to explain what happened in the Greek case. Utilising historical evidence from the mid-1950s to the late-1980s, this paper confirms that problematic tax rules create difficulties for entrepreneurship and can lead to unproductive forms of it, as Baumol suggests. However, the focus here is on aspects of the system of taxation that Baumol's model, examining solely tax rates and levels of taxation, neglected. It is shown that, as far as Greek entrepreneurship is concerned, the adverse effects of the system of taxation came not from the level of taxes, but mostly from a series of issues that increased its perceived unfairness and illegitimacy. Some of such issues were the complexity and frequent change of legislation, the insufficient organisation of the tax bureaus as well as the lack of adequate training and arbitrariness of the members of tax services. The evidence presented here suggests that Baumol's model can be enriched by taking into consideration these aspects of taxation too.
\end{abstract}

Keywords: Entrepreneurship, William Baumol, Institutions, Tax System, Greece

\section{Introduction - An opportunity to examine Baumol's theory}

In his famous 1990 article on productive, unproductive and destructive entrepreneurship, William Baumol argued that the rules of the game in an economy, such as for example tax rules, create incentives that influence entrepreneurship in different ways and allocate it between either productive activities (e.g. innovation), or unproductive activities, such as rent seeking and organised crime. As he wrote, '[h] ow the entrepreneur acts at a given time and place depends heavily on the rules of the game -the reward structure in the economy- that happen to prevail. ${ }^{1}$ 
Referring also to Assar Lindbeck's work, who demonstrated that in high-tax environments entrepreneurs channel their efforts to unproductive entrepreneurship such as financial speculation or even illegal activities, ${ }^{2}$ Baumol noted that 'taxes can serve to redirect entrepreneurial effort'. ${ }^{3}$ Generally, when writing about 'taxes' or 'tax rules' in his 1990 article, Baumol referred to the level of taxation. ${ }^{4}$ The same holds for his subsequent works. ${ }^{5}$

This article suggests that Baumol's focus on the level of taxes would be too narrow to examine the emergence of unproductive entrepreneurship in Greece. The evidence presented here suggests that the obstacles that the tax system created for Greek entrepreneurship came from the way it functioned, not the level of taxes. This seems to be the case from the various complaints expressed and the communications issued by entrepreneurs and their representative bodies, but also through an examination of relevant macroeconomic data. For example, entrepreneurs' total tax burden had had a significant long-term decline throughout the period of analysis. Specifically, the data that Tatsos presents, concerning the total tax burden distribution throughout the period 1960-1998, indicate that in 1960 entrepreneurs bore $50.9 \%$ of the total tax burden, a rate that was reduced to $41.2 \%$ in $1970,29.8 \%$ in 1980 , $25.3 \%$ in 1990 and $22.8 \%$ in $1998 .^{6}$ Also, in Greece, the share of taxes on income, profits and capital gains (but also that of total tax revenue) over GDP was significantly lower than the OECD average. ${ }^{7}$ Moreover, after the mid 1970s, it was not entrepreneurs who bore the majority of the tax burden in Greece, but salaried employees. ${ }^{8}$ It is equally important to note that the Greek tax system has traditionally been based upon indirect taxes. This has been attributed to a number of reasons, such as for example the incapability of the tax auditors to capture the tax accruing from business income and the income of the wealthier classes. This again indicates that the main disincentive the tax system posed for Greek entrepreneurs was not the level of taxes they paid, as the traditional form of Baumol's model would suggest, however much they might complain about this.

The evidence presented in this paper shows that it was the way that the tax system functioned that was posing a systemic threat to Greek entrepreneurs' activities. There were complaints and criticism about the functioning of the tax system and its effect on business throughout the period under examination. However, the impact of such problems was less explicit during the years of rapid economic growth, that is, from the mid-1950s up to about the mid-1970s. From this point onwards, there was a deterioration in the economy that made such problems significantly more pressing. 

Zolotas wrote that the Greek economy was 'in a particularly precarious state, being characterised by recession, a high rate of inflation and a serious deficit in the balance of payments'. ${ }^{9}$ The economic downturn gradually intensified, getting the form of stagflation, increasing deficits and deteriorating competitiveness. ${ }^{10}$ In this context, 1980 marked the beginning of a period characterised by low growth rates and deterioration in all the indicators of the degree of dynamism in the economy, and especially that of the percentage of investment to GDP. ${ }^{11}$ Also, according to Bank of Greece data, from 1985 to 1990 the growth rate of GDP got significantly reduced from $3.39 \%$ to $-0.35 \% .{ }^{12}$ Public deficit and debt as a percentage of GDP were also increased throughout the decade, from $-2.6 \%$ and $28.6 \%$ in 1980 to $-14.4 \%$ and $69.9 \%$ in 1989 , respectively. ${ }^{13}$ Such negative developments were accompanied by an exacerbation of the problems in the way the tax system functioned, primarily because of the increase in the complexity and the frequency of change of tax legislation, as will be shown in the next pages. In this framework, the problems caused by the tax system gradually became more explicit.

This paper suggests that the explanatory power of Baumol's model can be enhanced by taking into consideration the importance of the tax regime as well, and examining how the way that the tax services function affect entrepreneurship.

In fact, Greece is not unique when it comes to this matter, as the problems of tax administration are currently a topical issue in a number of European states. This is indicated through the European Commission's 2014 Competitiveness Report, which contained the results of a survey exploring the dimensions of public administration that most impede firms' operations across a number of European countries. ${ }^{14}$ The finding of the survey was that the most severe obstacles to firm growth are tax administration (not tax rates), corruption and ineffective justice systems. ${ }^{15}$ In other words, tax administration is perceived as a common problem in many European states. Due to this reason, the implications of the examination done here can prove useful not only for Greece but for these countries too.

In terms of the distinctions of the uses of history proposed by Kipping and Üsdiken, this research follows the approach of historical cognisance. This is because the analysis is driven by a 'history to theory' perspective, by examining the validity of a theoretical model, being however, at the same time, heavily contextualised. ${ }^{16}$ 


\section{Baumol's contributions on institutions and entrepreneurship}

William Baumol is considered to have pioneered the importance of institutions for entrepreneurship, ${ }^{17}$ maintaining that a reallocation of entrepreneurial efforts towards productive activities can be achieved through a change in the 'rules of the game', that is, in the way that institutions function in a society. ${ }^{18}$

Baumol's work is set within the wider framework of research suggesting that cross-country differences in long-term economic performance can be seen as the result of differences in these countries' institutional set up. Works such as that of North and Acemoglu and Robinson are prominent examples of such strand of literature. ${ }^{19}$ Of course, Baumol's contribution was focused specifically on entrepreneurship. ${ }^{20}$ Using examples from history, he showed that the relative payoffs that society attributes to each kind of activity, that is, the 'reward structure' of society, is what determines the allocation of entrepreneurship into various activities. ${ }^{21}$ In more detail, he maintained that Schumpeter's list regarding what could be considered as innovation in an economy (that is, technological improvement, a new good, a new method of production, an opening of a new market, a new source of supply of raw materials or the emergence of 'the new organization of any industry' $)^{22}$ should be extended so as to include 'items such as innovation in rent seeking procedures'. ${ }^{23}$ In such a case, entrepreneurship can be unproductive, or even destructive.

The decisive factor determining whether entrepreneurship will focus on productive or unproductive activities is the set of institutions influencing the relative payoffs attributed to different entrepreneurial activities. As Baumol wrote in a subsequent article, 'when the supply of productive entrepreneurs declines this is likely to be attributable not to an autonomous contraction in the total number of innovating entrepreneurs, but to a change in the structure of rewards that has led entrepreneurs to transfer their innovative talents from production to rent seeking or worse'. ${ }^{24}$

Therefore, according to Baumol, the term 'unproductive entrepreneurship' encompasses a large spectrum of activities: rent seeking through takeovers, litigation, tax avoidance and even tax evasion schemes are all unproductive activities, having an entrepreneurial character 
though, given the possible rewards yielded and the effort exerted by business executives to pursue them. $^{25}$

In later works, Baumol proposed further distinctions of entrepreneurship. For example, in 1994 he referred to innovative, imitative, unproductive and rent-seeking entrepreneurship, but also to entrepreneurship as business founding and management. ${ }^{26}$ In 2007 he wrote of innovative and replicative entrepreneurs, ${ }^{27}$ and in 2010 of redistributive and productive ones. $^{28}$

\section{The effect of taxation on entrepreneurship}

It should he noted here that a large part of the literature examining how taxes affect entrepreneurship does not make any clear distinction between various aspects of taxation. For this literature, the functioning of the tax system is either not discussed at all or considered as one of the many components of 'taxation' - but there is no special focus on how it affects business. An example of such literature is the work of Robin Douhan and Magnus Henrekson. They note that when the cost of abiding by tax regulations increases, tax evasion increases too, but also that when the level of taxes increase, entrepreneurs are channeling their efforts towards unproductive forms of entrepreneurship, such as tax avoidance. ${ }^{29}$ Similarly, Henrekson notes that the effects of taxes on entrepreneurial behaviour are complex because of the 'complexity of the tax code' ${ }^{30}$ However, his main interest is in examining the effects of tax rates on business activity and entrepreneurial behaviour, arguing that 'high taxes may spur self-employment but reduce productive entrepreneurship'. ${ }^{31}$

The absence of any special focus on the functioning of the tax administration also holds for a significant part of the literature that has utilised Baumol's model in order to examine the effect of taxation on entrepreneurship. Here, again, the main interest is on the level of taxes. An example of such literature is the work of Larroulet and Couyoumdjian, which investigates the relationship between entrepreneurship and economic growth in Latin America. Focusing on the institutional factors that Baumol's model examines, they too referred to taxation in terms of the extent of the tax burden. ${ }^{32}$ Similarly, in their examination of the institutional tax setup in Sweden, Edmark and Gordon showed that the level of tax rates affects companies' organisational form in the country. ${ }^{33}$ 
Again, the purpose here is not to claim that the role and importance of tax administration has been totally disregarded by the literature. A work that refers to the functioning of the tax system as well is that of Russell Sobel, who tested the validity of Baumol's model using an econometric perspective. Sobel also mainly focused on tax rates, however, when suggesting institutional reforms that would support productive entrepreneurship, apart from a reduction of the level of taxation, he also proposed the simplification of tax codes. This could be done, as he noted, in order to 'reduce the ability of groups to lobby for specific exemptions, credits, and rate reductions. ${ }^{34}$ A similar perspective is followed by Coyne and Leeson, on their analysis of the Romanian case. Identifying tax evasion as evasive entrepreneurship, the authors argued that it is to a great extent an outcome of the 'oblique and rapidly changing Romanian tax code'. ${ }^{35}$ Also, they noted that according to the 2003-2004 Global Competitiveness Report, Romanian entrepreneurs found tax regulations to be the most serious obstacle for doing business in the country. ${ }^{36}$ What makes the present study different from such works is the fact that, here, the functioning of the tax administration is not just one of the factors of interest, but the main focus of it. Of course, a further distinguishing characteristic is that the analysis done here is a historical one, with the use of relevant data. As will be discussed next, Baumol's model seems to be ideal for historical analyses of entrepreneurship.

\section{Baumol in historical studies}

That Baumol's model fits very well with the use of historical perspectives when examining entrepreneurship has been noted by Geoffrey Jones and Dan Wadhwani. They stressed that his work 'provides an excellent illustration of how a critical understanding of historical context and variation can help create useful and robust generalizations that are nevertheless bounded by time'. ${ }^{37}$ In general, as the authors note, entrepreneurial processes are embedded in certain institutional and historical settings, ${ }^{38}$ therefore 'many of the most interesting and intriguing research questions about entrepreneurship beg for institutionalist methodologies' ${ }^{39}$

The great scope for business history research to engage with Baumol's theory has also been highlighted by Walter Friedman and Geoffrey Jones, who, in an article in the Business History Review stressed the need to test his theories - specifically, his distinction between productive and unproductive entrepreneurship - from the perspective of historical experience. ${ }^{40}$ However, the majority of business and economic history literature that has 
referred to Baumol has just used his ideas, rather than attempting to explore their validity. ${ }^{41}$ An exception to this tendency has been the work of Ortiz-Villajos and Sotoka, who examined the determinants of entrepreneurial success in $20^{\text {th }}$ century Spain. ${ }^{42}$ The authors referred to Baumol's expanded list of what constitutes innovation in Schumpeterian terms and confirmed his position about the importance of the institutional environment for entrepreneurship. ${ }^{43}$ However, their analysis considered the institutional environment as a whole, without having any special interest on the system of taxation per se. This is what the contribution of the present paper will be, by focusing on the case of post-Second World War Greece and exploring the interaction between the system of tax administration and entrepreneurship in the country.

\section{Greek tax system and entrepreneurship, 1950s-1980s}

When the independent Greek state was established right after the end of the Second World War, the tax system's primary scope was to collect revenues, without having any significant redistributive and social dimensions. As Giouras and Psalidopoulos' work indicates, this was also the character of tax policies followed by the German occupation forces during the war. ${ }^{44}$ Due to this reason, people saw the tax system mostly as a mechanism that 'drained' money away from their pockets and this naturally made them eager to avoid paying taxes. To this also contributed the fact that the distribution of the tax burden was considered unfair, because, among others, as Tatsos notes, the burden for the lower income brackets was significantly higher than that of the higher ones. ${ }^{45}$ Perceptions about the unequal distribution of the tax burden in Greece contributed to the problem of tax evasion, which, as a relevant study by Kalyvianakis et al. suggests, ${ }^{46}$ started growing significantly from the late 1970 s, contributing, in turn, to a continuously growing public deficit.

Another characteristic of the tax system that made it unfair by contributing to the unequal distribution of the tax burden, thus also increasing incentives for tax evasion, was the preferential tax regime of the farmers. As Dertilis mentions, the legislative order 3323/1955 that concerned individual income taxation established a 'very high tax-free threshold, which virtually exempted agricultural income from any kind of taxation. ${ }^{47}$, Overall, until the decade of the 1990s, the participation of agricultural income in the state's total tax revenues amounted to less than 1 per cent until the decade of the 1990s (ibid). ${ }^{48}$ 
Also, there was a series of tax rebates that provided significant tax relief for the higher income classes and small or no relief for the medium and lower ones. ${ }^{49}$ Throughout the period 1960-1998 the per capita tax exemptions and rebates given to the financially stronger classes of industrialists, traders and freelance professionals increased much more rapidly than those given to other classes, such as pensioners and salaried employees. ${ }^{50}$

This again indicates that the main disincentive the tax system posed for Greek entrepreneurs was not the level of taxes they paid, as the traditional form of Baumol's model would suggest. Specifically, in the report of the Governor of the Bank of Greece for 1980, it was mentioned that for the promotion of investment in the country there should be a reexamination of a series of disincentives that had the form of state regulations and 'interventions in the economic life'. Such disincentives, stressed the Governor Xenophon Zolotas, created obstacles 'to the smooth function of the market [and] the rational allocation of resources', but also 'neutralis[ed] and render[ed] ineffective any developmental incentives and inhibit[ed] the assumption of business initiative... ${ }^{, 51}$ In about the same time the Bank of Greece produced a study that analysed such disincentives, burdening predominantly the industrial sector. ${ }^{52}$ The study was conducted by the so-called Disincentives Committee, presided by Zolotas, with the participation of the 'productive classes', which had been called upon to 'point out...the circumstances or law provisions that created obstacles or confusion and had halting effects on entrepreneurial activities'. ${ }^{53}$ One hundred and three professional bodies and individual companies participated in the initiative, among which were the Federation of Greek Industrialists, the Athens Chamber of Commerce and Industry and various other Chambers of the country, as well as the Union of Corporations and Limited Liability Companies. ${ }^{54}$ According to the study, there were disincentives relating to exports, disincentives relating to production and investment, financial disincentives, but also tax and fiscal disincentives. There were 13 different types of disincentives belonging to this last category, 7 of which related to the problematic functioning of the tax administration. These 7 types of disincentives had to do with a) the fact that tax audits were not taking place with the same standards every year, b) the fact that tax audits were very often delayed and as a result tax payers were not informed in time about their tax obligations, c) issues concerning the functioning of the tax justice and the fact that there was not any code of legislation concerning the adjudicating of tax cases, d) the fact that errors and omissions in tax books were often treated as cases of wilful concealment of income and thus punished accordingly, e) delays in the reimbursement of customs duties and other taxes, f) issues such as the fact 
that some taxes were levied on a retroactive basis and the fact that tax penalties were not lifted in cases were certain errors in tax books were due to false guidance given by the tax authorities themselves and g) issues such as the continuous changes and the complexity and lack of clarity of the tax laws. ${ }^{55}$

\section{Complexity of legislation}

The complexity, obscurity and continuous changes of the tax legislation were major issues burdening the Greek tax system throughout the period examined in this paper. According to the proceedings of the first national accounting congress in 1957, tax justice in the country functioned under a 'labyrinthine' regime. ${ }^{56}$ This problem of high complexity related, it was noted, to the unsuitability and incompetence of the bodies responsible for handling tax disputes. ${ }^{57}$ Similarly, in his speech in the second congress of the Chambers of Commerce and Industry of Greece, the president of the Chamber of Commerce and Industry of Thessaloniki referred to an $\mathrm{OEEC}^{58}$ report for Greece which mentioned that ' $[\mathrm{t}]$ here is no hope that firms will reach the apex of their efficiency...with no clear, specified and effective dissemination of information. In Greece many factors oppose this. The most important one is the State's strict and detailed inspection of the accounting books of firms, which forces industry to engage in dull paperwork, which is not met in...industrially advanced countries' ${ }^{59}$

Similarly, in a meeting with the minister of Economics in 1965, the president of the Chamber of Commerce and Industry of Piraeus, Nikos Svoronos, ${ }^{60}$ noted that 'sometimes, the procedures and prerequisites for some pieces of legislation are so complex that the entrepreneur waives his right to use them, resulting in a non-fulfillment of the scope of the legislation'. ${ }^{61}$ In the same vein, it was mentioned in an August 1970 issue of the Bulletin of the FGI that according to a tax expert, 'having three tax officers separately auditing the accounting books of a large company and making the same assessment for the level of its [taxable] income, would be a random coincidence, under the current tax regime. ${ }^{, 62}$ The law 185 against tax law offences that had been introduced in 1967, that is, when Greece was ruled by a dictatorship, was criticised for precisely the same reason. It was stressed that the law needed to change, because some parts of it were 'clear disincentives for private entrepreneurial initiative. ${ }^{63}$ The law set the procedures of criminal prosecution against those 
who were accused of having broken 'paragraph 4 of the $5^{\text {th }}$ article of the Tax Code and article 3 of the legislative order $3848 / 1958^{\prime}$ by affecting the validity of accounting books. In its initial form, the law, entitled 'On the imposition of penal sanctions against tax law offenders' stated that owners or managers of Greek companies and managers or representatives of foreign companies based in Greece being accused of such acts would be called before emergency military courts. ${ }^{64}$ The law continued to operate after the fall of the dictatorial regime in spite of the fact that it was often criticised of being a 'sword of Damocles' that 'unexpectedly criminalised the country's economic life, being introduced without the prior...establishment of modern Economic Laws, and being based mostly on the excessive formalism [and] improvisation of the Tax Code' ${ }^{65}$

In roughly the same period, in the sixth Congress of the Chamber of Commerce and Industry of Greece it was mentioned that 'the frequent changes of the tax legislation and other surprise alterations and contradictory policies' were serious disincentives for the country's economic development. ${ }^{66}$ Entrepreneurs that were interviewed for this research and who have been active in the Greek industry since the late 1970s supported the same view. One of them, Stelios Argyros, ${ }^{67}$ noted the following:

I do not think that it could be argued that companies in Greece were ever overtaxed, because there has been a series of measures that reduced the tax burden, such as tax incentives...on the other hand, companies in Greece were never taxed in a stable manner. They never had even a five years horizon so as to know on the basis of which tax policies they should program their commercial and industrial plans. This is an obstacle for good entrepreneurship. For bad entrepreneurship, it is not an obstacle, because people involved in it consider the non-payment of taxes to be an obligation, even in a low-tax environment. ${ }^{68}$

Apart from showing that the constant changes in the tax law framework were unsettling for business, this view elucidates Baumol's idea about forms of 'unproductive entrepreneurship ${ }^{69}$ - in this case, entrepreneurship that focuses mainly on evading taxation- that arise in environments in which institutions such as the system of taxation do not function properly.

In the same vein, the annual activity report for 1979 of the Union of Corporations and Limited Liability Companies mentioned that for the advancement of private investment, political, economic and financial stability, but also tax stability and consistency were needed. However, it stressed that such conditions were not met in the case of Greece and that the tax 
system was anything but stable: there were only 'continuous changes' in it, which, combined with the various special contributions and other taxes, created a picture of 'striking tax instability, prohibitive of investment activities' ${ }^{70}$ It was also mentioned in the press that in a period of 'desperate efforts' for the promotion of investment, 'sudden' tax measures, increased the uncertainty of the 'business owner-investor'(I Kathimerini, January 21, 1979).

It must be noted here that, as mentioned in the beginning of this article, the problem of the complexity of tax legislation seemed to start becoming a more pressing issue from the mid1970s onwards. The reasons for this are manifold. First of all, it is important to note that Greece experienced a seven year military dictatorship period from 1967 to 1974 . During these years the situation in the tax services worsened, because there were a large number of dismissals of civil servants that were regarded to be disloyal to the junta. This contributed to the dismantling of the Central Service of the Ministry of Economics, which was responsible for controlling the function of tax bureaus. Under such conditions, it seems that during the dictatorship the tax system not only kept on posing difficulties to business and therefore to industry too, but also entered a phase of very rapid deterioration in the quality of its administrative structures.

Indeed, as Zolotas noted in 1975, the dictatorship left public organisations and the broader public administration in a state of 'generalised disruption'. ${ }^{71}$ Adding to this point, in an article originally written in 1995, Photopoulos noted that the dismantling of the Central Service of the Ministry of Economics by the dictatorial government 'was a severe blow to the creation of executives of high scientific standards; its results became obvious several years later, with the decline in the quality of the tax bills that were proposed in the Parliament and of the interpretative statements issued [by the Ministry of Economics] in cases of controversial [tax] matters. ${ }^{72}$ Confirming Photopoulos' point in a more general sense, Kazakos noted that the people the junta appointed as executives in the various ministries were 'distinctively uneducated. ${ }^{, 73}$

After the fall of the junta, the problems with the functioning of the tax mechanisms worsened. The impact of the dismissals of officers during the period of dictatorship kept burdening the tax administration, which also had to deal with a significant increase in the tax legislation's frequency of change. Also, as relevant studies have indicated, there was an increase in the tax burden after the fall of the coup regime. ${ }^{74}$ The new pieces of legislation that the post- 
dictatorial government introduced resulted in the imposition of new taxes or the increase of the burden of the already existing ones. These were legislative order 84/1974 as well as laws 231/1975 and 254/1976 introducing new taxes, law 12/1975 regarding the increase of already existing taxes, and law 11/1975 regarding property taxation. ${ }^{75}$ In this climate, in summer 1977 and during the sixth Congress of the Chamber of Commerce and Industry of Greece the leader of the main opposition party in the Parliament, Georgios Mavros, noted that in order to take advantage of its association with the EEC, Greece needed an environment conducive to development. For this, the state needed to implement 'clear policies', as what long-term business planning needed was 'a climate of trust and stability'. Yet, 'the frequent changes of the tax legislation and other surprise alterations and contradictory policies' were serious disincentives for the country's economic development. ${ }^{76}$ In the same vein, the annual activity report for 1979 of the Union of Corporations and Limited Liability Companies mentioned that for the advancement of private investment, political, economic and financial stability, but also tax stability and consistency were needed. However, it stressed that such conditions were not met in the case of Greece and that the tax system was anything but stable: there were only 'continuous changes' in it, which, combined with the various special contributions and other taxes, created a picture of 'striking tax instability, prohibitive of investment activities'. ${ }^{77}$

On the other hand, the constant imposition of new taxes (and the resultant increased complexity of the system) were part of the government's efforts to sustain the increased expenditure of the budget, as they were accompanied by policies that clearly aimed to increase tax revenues such as the increase in the taxation of dividends, the imposition of capital gains taxation upon real estate owned by firms, the increase of turnover tax and the acceleration of the procedures governing the assessment and collection of excise duties. ${ }^{78}$

The situation did not change with Greece's accession to the EEC in 1981. Maybe this was because, as it has been argued, the country's authorities had seen the procedure of the accession to the EEC as a predominantly political matter. That is, they did not pay sufficient attention to the economic repercussions of it and did not place the economy to the centre of the negotiations preceding the accession, something that would have probably led to the beginning of an effort of restructuring of it. ${ }^{79}$ According to Zacharias Demathas, when Greece entered the European Union, it was accompanied by the problems of the 1970s, and specifically, high inflation, an economy controlled by the state, but also 'deficient infrastructure, mechanisms and institutions, ${ }^{80}$ 


\section{The role of the tax authorities}

The arbitrary way with which the tax authorities functioned and the role of the tax officers during audits was an additional problem, one that was even more irritating than that of the complexity of legislation. This is what an examination of the complaints raised by entrepreneurs suggests. Such complaints ultimately questioned the tax officers' ability to adequately perform their duties: 'The directors of the tax offices, being, in their majority, ignorant of accounting, increase the profits of [the audited books], totally arbitrarily and unjustifiably', argued one of the entrepreneurs' representatives in $1957 .{ }^{82}$

The way that tax officers appeared to behave during audits was often described to be unnecessarily aggressive. Significantly, this was acknowledged by members of the government. For example, according to a 1959 study entitled 'Measures against tax theft', 83 the legislative order $3848 / 1958$ on business income taxation set that the audit reports leading to the rejection of accounting books would be examined by Advisory Committees. ${ }^{84}$ It was noted, however, that such committees' decisions almost always coincided with the audit reports that rejected the books. Apart from this, the reports that the committees issued were lengthy and 'written in a pointlessly adversarial spirit'. It was stressed in this study that this had to change and that strict measures such as the rejection of accounting books should be avoided: 
A timely intervention is needed before honest taxpayers... become very upset and start resorting to acts of tax fraud or non-keeping of accounting books. The auditors and the members of the Advisory Committees have to understand that rejection of the accounting books...is an event that causes great suffering to the taxpayers, and should take place in totally extraordinary cases. ${ }^{85}$

There was not any clarification with regards to what those extraordinary cases might be, but it seems that the reference was to cases in which the mistakes and/or omissions in the accounting books indicated tax evasion. Also, from the wording of the study, it seems that the problem with such advisory committees was that they did not seem to serve the role they had been created for: to check and control the tax auditors. Instead, for the most part, their decisions were in accordance to those of the tax auditors and they did not act as a check or balance.

Tax officers' arbitrariness was an issue that was openly discussed by entrepreneurs too. For instance, in the 1957 congress of the Chambers of Commerce and Industry of Greece the president of the Chamber of Commerce and Industry of Epirus noted that the tax system allowed for compromises to take place between taxpayers and tax officers. Such compromises were achieved after the two parties negotiated with regards to the tax that would have to be paid. Of course, the very fact that such negotiations did take place increased the degree of arbitrariness of the tax system in general, and, more specifically, the arbitrariness in the behaviour of the tax officers. Even worse, such negotiations and compromises were deemed necessary by the taxpayers, it was noted, because taking legal actions would prove useless. In more detail, in the president's words, any taxpayer in such an occasion would think of the following way:

If I take legal actions, would it ever be possible for me to expect any further gain, especially from a second-degree court that is chaired by a...[Judge] who has no knowledge of such matters and an Economic Inspector who is undoubtedly a mouthpiece, if not an extension, of the inclinations and the aims of the Tax Officer? ${ }^{86}$

Some characterised the whole process of negotiations and compromises with the tax authorities a 'torture' ( $\mathrm{Ta} \mathrm{Nea}, 20$ October 1962) and relevant references appeared in politicians' speeches too:

Even for the slightest reason, the accounting books of merchants and industrialists get rejected..., and instead of a tax of, say, DRS 10,000, the tax auditor, through the rejection of the books, imposes a flat tax of DRS 100,000, and then asks the owner of 
the industry to compromise... The reduction of any kind of tax rates has no effect when, through another door, that of classifying the tax payer to a higher tax bracket than the one he really belongs, the State oppresses the taxpayer and exercises over-taxation (Eleftheria, 3 August 1962).

Problematic relations with the tax officers also led to the non-fulfilment of legislation, such as for example tax incentives that had been introduced for the promotion of investment. Indeed, in the fifth Congress of the Chambers of Commerce and Industry of Greece, the President of the Chamber of Commerce and Industry of Heraclion, referring to three tax incentives laws aiming particularly to the development of regional industries (legislative orders $942 / 1949,2176 / 1952$ and law 321/1955), stressed that 'the benefits stemming from the incentives laws should be of a permanent nature, without being subject to cancellation and without depending on the judgment of tax auditors with regards to the sincerity of the regional industries' accounting books'. ${ }^{87}$

The Chamber also complained for the tax authorities' 'over-zealousness' when collecting tax revenues, mentioning that there had often been instances of inaccurate tax assessments 'that led firms to great troubles, or even to extinction' ${ }^{88}$ In fact, there were indeed measures that indirectly promoted such over-zealousness, by relating, for example, the compensation of directors of tax offices with the level of tax revenues that they would achieve. ${ }^{89}$

There were also cases in which the arbitrariness of the tax system stemmed not from the behaviour of individual officers, but from the general philosophy with which the tax legislation, the tax services, but also the Ministry of Economics functioned. For example, in a Board Meeting in the Union of Corporations and Limited Liability Companies in 1975, it was mentioned that if a firm disagreed with the tax authorities' decision about the tax that had to be paid and appealed to the courts, it was obliged to pay the full amount of tax due in a single payment. On the contrary, if it compromised with the tax authorities, it could pay it in 8 instalments. For the Union, such legislation indirectly forced firms to accept an 'onerous compromise'. ${ }^{90}$

In the same meeting, the vice-president of the Union noted that the tax services ranked firms in various classes and 'decided in advance how much more tax each one should be paying'. 91 What he meant with such a comment was that, regardless of the information contained in 
companies' accounting books, tax audits would always result in such companies paying more taxes than those that would normally correspond to the economic results they declared.

Apart from the role of the tax authorities during audits, entrepreneurs complained also about policies of a more general character that the Ministry of Economics implemented in order to tackle tax evasion. For example, whereas, in July 1982, the Ministry had declared that the names of tax evaders would be publicised only after the relevant courts issued their final judgments (I Kathimerini, 23 July 1982) the opposite tactic was followed in later years.

In October 1988 the Chamber of Commerce and Industry of Athens characterised the Ministry's announcements with regards to transgressions of the tax legislation by banks, oil companies and commercial and industrial enterprises, as 'unacceptable defamations', attempts to influence the judicial authorities and actions that were besetting the business and investment climate. The president of the Chamber Andreas Kyriazis noted that the cases of companies that had been found guilty of tax evasion by the relevant courts were 'socially unacceptable and economically condemnable'. Yet, the cases that had recently come to light, he stressed, involved companies that were merely having differences with the tax authorities, mainly because of different interpretations of the tax laws. ${ }^{92}$

On the same issue, it was noted in the Bulletin of the FGI in November 1988, that even before the relative cases were examined in courts, the state publicised the names of companies the taxable income of which was set higher than the one they had declared in their tax returns. This led to those companies' 'public vilification', and harmed both the relations between taxpayers and the authorities and the business climate. 93

\section{Corruption}

What also harmed relations between taxpayers and the authorities were the cases of corruption that often appeared in the media, usually involving members of the tax services asking for bribes. In the study 'Measures against tax theft' mentioned previously, it was noted that control of the works of the tax services was 'shadowy and in most cases nonexistent', and that therefore, the establishment of inspection agencies of the various tax offices was necessary. ${ }^{94}$ It seems that the use of extortionary tactics by tax officers during audits were not a rare occasion. For example, cases such as the one of two tax officers who 
were brought into custody with the accusation of blackmailing a factory owner 'in order to extort DRS 6,000 from him...through the issuing of a favourable audit report'(Ta Nea, 27 April 1956) made appearances in the press. In newspaper articles, sometimes tax officers were described as people that had the ability to 'burn' the taxpayer:

[The tax collector] is the one who assesses [the taxpayer's] profits, audits his books and estimates how much he has to pay. If he wants to, he can make an estimation of 10 million. If he wants to, he makes one of 1 million. If he wants he accepts the accounting books, if [not] he rejects them. Therefore, the easiest thing for him is to blackmail the taxpayer (Ta Nea, 12 February 1955).

Throughout the period analysed in this paper, there were many references in the press about incidents where tax officers were arrested for blackmailing and bribery. In most of the cases tax officers were accused of asking owners of companies for a bribe in order to not examine the company's accounting books, or to reduce (or not impose at all) the fines that had to be paid because of mistakes found in such books. ${ }^{95}$ It was common in the cases referred to here that they came to light after the owners of the blackmailed companies filed reports to the police. Of course, it should certainly be expected that, in general, there would also be business owners - or taxpayers, more broadly - who would prefer to pay bribes, encouraging thus corruption and contributing to the problem of tax evasion. Still, that there were also people who preferred to complain to the police indicates that tax officers' corruption was a real issue that harmed business; if this was not so, every owner of a blackmailed company would simply pay the bribe, without making any kind of complaint to the authorities. This was not the case, however. On the contrary, the situation with corrupt tax officers created an adverse climate, indicative of which is the following point made by the pre-mentioned entrepreneur Stelios Argyros:

It would help if the tax system was stable and structured in such a way that the taxpayer did not come into contact with the tax officers. For example, in the US, tax audits take place on a random basis, and therefore the entrepreneur does not work thinking that 'tax officers will be coming every month and blackmail me'. He also knows however that if he is found to have gone against the law in one of these random checks, he will end up in prison. Because of this, he complies with tax legislation. ${ }^{96}$

Moreover, there were laws that had been introduced in order to curb tax evasion and tax officers' corruption, which, however, most of the time, also increased tax officers' authority and thus, their potential arbitrariness. For example, in January 1978, the formation of special tax inspection teams was announced, in order to contribute to the fight against tax evasion. 
These teams of tax officers were characterised by the front pages of the press of the period as 'commando-like' groups ${ }^{97}$ that would have the authority to act as the police, carrying out surprise inspections on professionals' and companies' accounting books and records, on a 24hour basis. Amongst the groups' responsibilities would be to daily inform the Ministry of Economics about their findings. The Ministry could then publicise the names of tax law offenders in cases of severe offences. More importantly, the inspection teams would have the authority to reject accounting books on a 'fast-track' basis and then determine taxable income ad-hoc, that is, disregarding any information about revenue and expenditure contained in the accounting books ( $\mathrm{Ta} \mathrm{Nea}, 26$ January 1978). In this context, some noted that tax evasion was used as a pretext by the government, which formed such inspection groups in order to start 'hunting for taxes' (Rizospastis, 26 January 1978).

The draft bill containing such measures was entitled 'On the assumption of measures against tax evasion and other relevant provisions' and got publicised by the government in 23 August 1978. Amongst its other provisions, the bill also announced the formation of the body of Sworn-in Valuers, having as its main purpose the valuation of property for taxation related matters. In a parliamentary discussion, Athanasios Krikos, an MP of the ruling party New Democracy, noted that the Body would protect the taxpayers from the tax officers' arbitrariness, who, 'in order to ingratiate themselves with their superiors, very often impose[d] higher taxes than they should' (I Kathimerini, 18 May 1979). Still, the general appreciation of the press was that the bill provided tax officers with 'excessive powers' (To Vima, 24 August 1978) and aimed to intimidate taxpayers introducing 'unprecedented penalties and fines' (ibid.). More specifically, and apart from the measures mentioned above, the establishment of services for the control of the movement of goods was decided, in which tax officers would have the authority to undertake investigating tasks even without a relevant order from a Prosecutor. The inspectors of the tax services would also have the right to perform investigations in order to retrieve the taxpayers' books and records, again even without a Prosecutor's order, but also the authority to order the re-examination of any tax case (ibid.).

For the Chamber of Commerce and Industry of Athens, the bill provided Inspectors of tax offices with increased powers, introduced 'crippling penalties' and 'handed the taxpayer over to the uncontrollable judgment of the directors of tax offices'. ${ }^{98}$ It is characteristic that at the time, the state itself openly acknowledged how rampant the problem of corruption was. 
Indicatively, even the Secretary of State Konstantinos Stephanopoulos admitted, in a relevant Parliamentary discussion in 1981, that apart from bureaucracy, one of the main problems of the public sector was that there were many services in which bribing was a standard practice. ${ }^{99}$ In the same vein, a retired tax officer that participated in this research noted:

At around 1980 the director of my department was talking about an officer who, with the things he did, earned a second salary. For example, he issued certificates; if you bribed him, he issued them faster. Or, in the department where they stamped (for authentication purposes) the accounting books and records, he wouldn't stamp, say, 10 invoice books, but only one, in order for you to have to come again [and bribe him]. This officer gave to the trade unionist of the ruling party his vote. And to this trade unionist he turned if he needed something, giving him of course, in return, some kind of 'gift'. 100

Indeed, numerous cases of tax officers being arrested for bribery appeared in the press throughout the period that is examined here. ${ }^{101}$ According to an article in the newspaper Rizospastis in September 1983, one such case led to the dismissal of two tax officers and the transfer of the director of the tax service to which they belonged. The person who revealed this specific case by complaining to the authorities was the owner of a handicraft industry, who also made the following statement: 'Groups of tax officers that are in charge of performing audits...operate in an organised fashion and blackmail owners of handicraft industries and shop owners'. The same person also argued that every time there was an audit of accounting books, tax officers 'created problems' for shopkeepers, blackmailing them in order to gain bribes 'in exchange for them keeping quiet' (Rizospastis, 18 September 1983).

\section{Conclusion}

William Baumol's research indicated that tax rules affect the development of entrepreneurship and influence the forms of it that can emerge in different societal and economic contexts. However, Baumol's examination considered exclusively the level of taxes. This paper takes his perspective a step further, by suggesting that the explanatory power of his model can be enhanced by taking into consideration the importance of the tax regime as well, and examining how the way that the tax services function affects entrepreneurship. 
The evidence presented here considers the interaction between the tax system and entrepreneurship in Greece from the mid 1950s to the late 1980s. The analysis suggests that for Greek entrepreneurship, the adverse effects of the system of taxation came mostly from a series of issues that increased its perceived unfairness and illegitimacy, such as the complexity and frequent changes of the tax laws and the arbitrariness of the tax authorities. Such problems had nothing to do with tax rates, which in fact were one of the very few features of the tax system that were certain and non-negotiable.

Of course, it is true that the information presented here is not derived from case studies of individual companies but rather from publications of business bodies of Greece such as the Federation of Greek Industrialists and the Chambers of Commerce and Industry of Greece, and also speeches, interviews and articles written by these bodies' representatives. The evidence also present politicians' views, the views of the wider public, as well as the views of the representatives of institutions such as the Bank of Greece. Such a variety of sources reflects, on the one hand, the issue of availability: it was difficult to obtain access to business archives containing information about a subject as thorny as the functioning of the tax system. The way that the tax system affected investment plans or any other aspect of business decision making was something that was not often discussed by Greek entrepreneurs, nor, rather, recorded in the relevant sources. To this could have contributed the fact that, as the bulk of evidence indicates, such discussions would most probably also contain references on tax evasion and / or corruption.

However, apart from the scarcity of material, the variety of sources employed in this research also reflects the need to corroborate the views expressed by business. For example, the complaints with regards to the arbitrariness of tax officers were expressed not only by entrepreneurs, but by individual taxpayers and politicians too, and the critique about the obscurity of the tax procedures came also from tax professionals and other experts. The consistency of evidence presented suggests that the complaints and criticism were not simply part of an anti-tax rhetoric voiced by entrepreneurs and their representatives, but that they truly reflected the general public's vexation caused due to the way the tax system functioned.

Overall, it seems that Greek entrepreneurs considered that the way the tax system functioned was posing a systemic threat to their activities and increased uncertainty, which was anything but beneficial for investing in business. 
Research based on the extended version of Baumol's model that is suggested here could provide useful insights about the interaction between taxation and business, especially for the cases of countries like Greece, in which tax administration seems to be a greater obstacle for entrepreneurial activity than tax rates. Of course, it should be noted here that the present analysis implied a dichotomy between productive and unproductive entrepreneurship. It is acknowledged however that, in the majority of the cases, as one of the reviewers of this article suggested, practicing entrepreneurs are usually dividing their time between productive entrepreneurship and activities that, according to the Baumolian perspective, are examples of unproductive entrepreneurship, such as, for example, tax avoidance. In other words, future research should also take into consideration that in reality entrepreneurial effort involves almost always a trade-off between productive and unproductive activities.

\section{BIBLIOGRAPHY}

Acemoglu, D. and James A. Robinson. Why nations fail: the origins of power, prosperity, and poverty. United States: Crown Publishers, 2012.

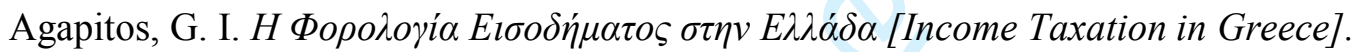
Athens: Centre of Planning and Economic Research, 1986.

Amatori, Franco. 'Busines History: State of the Art and Controversies'. Revista de Historia Industrial, 39, 1. (2009): 15-34.

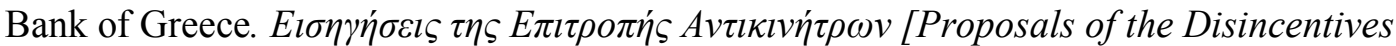
Committee]. Athens: Bank of Greece, 1979.

Bank of Greece Governor's Annual Report for 1980, 18

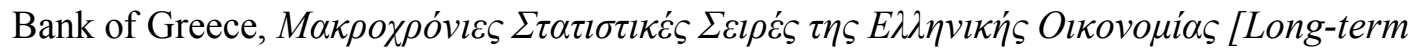
Statistical Series of the Greek Economy] Athens: Bank of Greece, 1992. 
Barbero, María Inés. "Business Groups in Argentina during the Export-Led Growth Period (1870-1914)', in Entrepreneurship and Growth - An International Historical Perspective, edited by Gabriel Tortella and Gloria Quiroga, 69-91. UK: Palgrave Macmillan, 2013.

Baumol, William J. “'Entrepreneurship: Productive, Unproductive, and Destructive', Journal of Political Economy, 98, 5, 1 (1990): 893-921. https://doi.org/10.1086/261712

Baumol, William J. "Formal Entrepreneurship Theory in Economics: Existence and Bounds'. Journal of Business Venturing, 8 (1993): 197-210. DOI: 10.1016/08839026(93)90027-3

Baumol, William J. Entrepreneurship, Management, and the Structure of Payoffs, Cambridge, Mass.: The MIT Press, 1993.

Baumol, William J. The Free-Market Innovation Machine: Analyzing the Growth Miracle of Capitalism. Princeton, NJ: Princeton University Press, 2002.

Baumol, William J., Robert E. Litan, and Carl J. Schramm. Good Capitalism, Bad Capitalism, and the Economics of Growth and Prosperity. USA: Yale University Press, 2009.

Baumol, William J. The Microtheory of Innovative Entrepreneurship. Princeton: Princeton University Press, 2010.

Baumol, William J. "The Entrepreneur in History'. In The Invention of Enterprise: Entrepreneurship from Ancient Mesopotamia to Modern Times, edited by David S. Landes, Joel Mokyr \& William J. Baumol, ix-xiv. Princeton: Princeton University Press, 2010.

Braunerhjelm, Pontus and Magnus Henrekson. "Entrepreneurship, Institutions and Economic Dynamism: Lessons from a Comparison of the United States and Sweden', IFN Working Paper No. 943, 2012, Research Institute of Industrial Economics http://www.ifn.se/wfiles/wp/wp943.pdf 
Broadberry, Stephen and Nicholas Crafts. "Competition and innovation in 1950's

Britain”. Economic History Working Papers, 57/00, 2000. Department of Economic History, London School of Economics and Political Science, London, UK.

Bulletin of the Chamber of Commerce and Industry of Athens, 1 January 1965, 16.

Bulletin of the Federation of Greek Industries, 17, 195, 15 August 1970, 1.

Bulletin of the Chamber of Commerce and Industry of Athens, July-August 1977, 7-8, 49-50.

Bulletin of the Chamber of Commerce and Industry of Athens, September 1978, 9, 27.

Bulletin of the Chamber of Commerce and Industry of Athens, May 1981, 5, 3.

Bulletin of the Chamber of Commerce and Industry of Athens, October 1988, 10, 3;16.

Bulletin of the Federation of Greek Industries, October-November 1988, 504, 7.

CHROTEX Archive, 'Tax Courts', 6.

Corley, T.A.B. "Firms and Markets: Towards a Theory of Business History', Business and Economic History, 22,1. (1993): 54-66.

Coyne, Christopher J. and Peter T. Leeson. "The plight of underdeveloped countries'. Cato Journal, 24, 3. (2004): 235-249.

Decker, Stephanie. "The silence of the archives: business history, post-colonialism and archival ethnography.” Management \& Organizational History 8, no. 2 (2013): 155-173. doi:10.1080/17449 359.2012.761491 
Decker, Stephanie, Matthias Kipping, and R Daniel Wadhwani. "New Business Histories! Plurality in Business History Research Methods". Business History 57, no. 1 (2015): 30-40. doi: 10.1080/00076791.2014.977870.

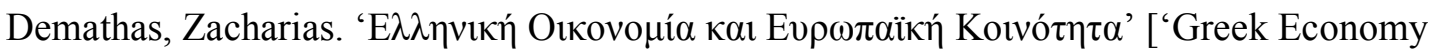

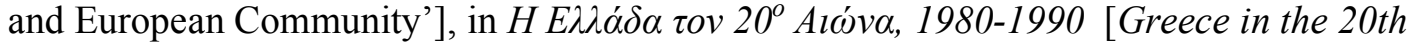
century, 1980-1990, 23-24. I Kathimerini - Epta Imeres. Athens: I Kathimerini, 1999

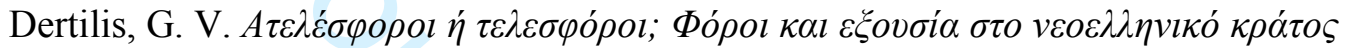
[Ineffectual of Effective? Taxes and Power in the Neo-hellenic State]. Athens: Alexandria Publications, 1993.

Douhan, Robin and Magnus Henrekson. "The Political Economy of Entrepreneurship"'. IFN Working Paper No 716, Research Institute of Industrial Economics, 2007.

Downs, Laura Lee. Writing Gender History. London: Bloomsbury Academic, 2009.

Edmark, Karin and Roger H. Gordon. "The choice of organizational form by closely-held firms in Sweden: tax versus non-tax determinants'. Industrial and Corporate Change, 22,1. (2013): 219-243. doi:10.1093/icc/dts045.

Estrin, Saul, Klaus E. Meyer and Maria Bytchkova. 'Entrepreneurship in Transition Economies', in The Oxford Handbook of Entrepreneurship, edited by Mark Casson, Bernard Yeung, Anuradha Basu and Nigel Wadeson, 693-725. Oxford: Oxford University Press, 2006.

European Commission, Helping Firms Grow, European Competitiveness Report 2014, Commission Staff Working Document SWD (2014)277 final $<$ http://ec.europa.eu/growth/industry/competitiveness/reports/eu-competitivenessreport/index_en.htm $>$ [accessed 12.3.2016]

Friedman, Walter and Geoffrey Jones. "Business History: Time for Debate”. Business History Review, 85, (2011): 1-8. doi:10.1017/S0007680511000201. 
Giouras, Thanasis and Michalis Psalidopoulos. Occupation, Nazism and Greek Economy Official Reports and Memoirs (Athens: Metamesonikties Ekdoseis, 2015), pp., 19-20; 34; 224-46, in Greek.

Henrekson, Magnus, 'Entrepreneurship and Institutions', IFN Working Paper No 707, Research Institute of Industrial Economics, 2007. http://www.ifn.se/Wfiles/wp/wp707.pdf

Jones, Geoffrey and Rohit Daniel Wadhwani. "'Schumpeter's Plea: Rediscovering History and Relevance in the Study of Entrepreneurship". Harvard Business School Working Paper, No. 06-036, 2006. http://www.hbs.edu/faculty/Publication\%20Files/06-036.pdf.

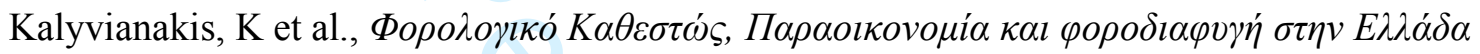
[Tax regime, Shadow Economy and Tax Evasion in Greece]. Athens: Papazisis, 1993.

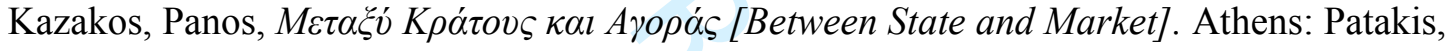
2001.

Kipping, Matthias \& Behlül Üsdiken. "History in Organization and Management Theory: More Than Meets the Eye', The Academy of Management Annals, 8:1, 2014: 535-588, DOI: $10.1080 / 19416520.2014 .911579$

Larroulet Vignau, Cristián and Juan Pablo Couyoumdjian. "Entrepreneurship and Growth: A Latin American Paradox?', The independent review: journal of political economy, 14, 10 (2009): 81-100.

Lindbeck, Assar. 'Consequences of the Advanced Welfare State', The World Economy 11:1. 1988: 19-38.

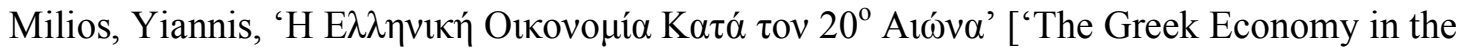
20th Century'] <http://users.ntua.gr/jmilios/Oikonomia_Eikostos1ab.pdf> [accessed 20.12.2014].

North, D. Institutions, Institutional Change and Economic Performance. Cambridge: Cambridge University Press, 1990. 
Ortiz-Villajos, José M. and Sonia Sotoka. “An Approach to Entrepreneurial Success and Its Determinants: The Case of by Gabriel Tortella and Gloria Quiroga, 133-172. UK: Palgrave

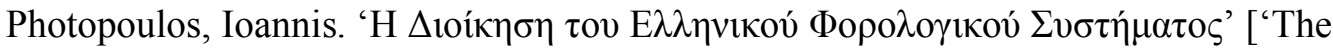
Administration of the Greek Tax System'], Enterprise, reprint, 63 (2010): 893-907

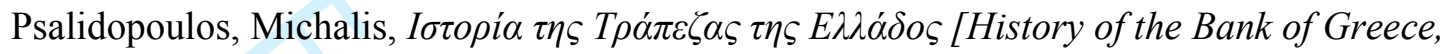
1928-2008]. Athens: The Bank of Greece, 2014.

Randolph, Gregory M., Michael T. Tasto and Robert F. Salvino. Public Policy, Productive and Unproductive Entrepreneurship: The Impact of Public Policy on Entrepreneurial Outcomes. UK: Edward Elgar Publishing, 2017.

Sobel, Russel S. "Testing Baumol: Institutional quality and the productivity of entrepreneurship'. Journal of Business Venturing, 23. 6. (2008): 641-155.

https://doi.org/10.1016/j.jbusvent.2008.01.004

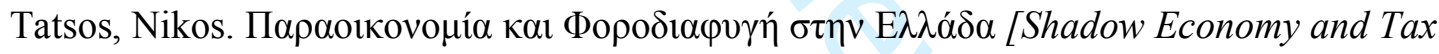
Evasion in Greece]. Athens: Papazisi, 2001.

Toninelli, Pier Angelo, Michelangelo Vasta and Emma Zavarrone. "Explaining Entrepreneurial Success: Evidence from the Italian Case (Nineteenth-Twentieth Centuries)", in Entrepreneurship and Growth - An International Historical Perspective, edited by Gabriel Tortella and Gloria Quiroga, 92-112. UK: Palgrave Macmillan, 2013.

Vovolini Archives, Viomichaniki Epitheorissis, Vol. 26, Proceedings of the 2nd Congress of the Chambers of Commerce and Industry of Greece, 20-23.10.1957, 53-4. The full report was published in the newspaper O EconomicosTahidromos ( 10 October 1957).

Welter, Friederike and William B Gartner. A Research Agenda for Entrepreneurship and Context. UK: Edward Elgar Publishing, 2016. 
Union of Corporations and Limited Liability Companies, Board Meeting Minutes 24 April 1980, 135-6.

Vovolini Archives, Viomichaniki Epitheorissis, Vol. 26, Proceedings of the 2nd Congress of the Chambers of Commerce and Industry of Greece, 20-23 October 1957, speech of A. Nikolopoulos, president of the Athens Traders Association, 73.

The 'Konstantinos G. Karamanlis' Foundation, 'Historical Archive', Konstantinos Papakonstantinou; http://www.ikk.gr/Default.aspx?tabid=236 .

The 'Konstantinos G. Karamanlis' Foundation, 'Konstantinos Papakonstantinou Archive', File 202A, Findings of the Economics Committee, 1959-1961, Notes on Tax Evasion, Measures against tax theft, 4.

Union of Corporations and Limited Liability Companies, Board Meeting Minutes 8 October 1975, 130.

Vovolini Archive, Viomichaniki Epitheorissis, Vol. 26, 1959, Proceedings of the 2nd Congress of the Chambers of Commerce and Industry of Greece, 20-23 October 1957, 268-9.

Vovolini Archive, Viomichaniki Epitheorissis, Vol. 32, 1965, Proceedings of the 5th Congress of the Chambers of Commerce and Industry of Greece - 8th theme of the agenda, 14-17 June 1964, 171.

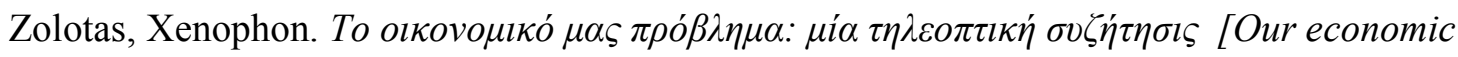
problem - a TV discussion]. Athens: The Bank of Greece - Surveys and Talks Archive, 1975.

NOTES

${ }^{1}$ Baumol, 'Entrepreneurship: Productive, Unproductive, and Destructive', 894.

2 Lindbeck, 'Consequences of the Advanced Welfare State', 27.

${ }^{3}$ Baumol, 'Entrepreneurship: Productive, Unproductive, and Destructive', 915.

${ }^{4}$ That is, he refers to rules that concern the level of the various tax rates (Ibid., 917). 
${ }^{5}$ See Baumol, The Free-Market Innovation Machine, 65,69 and Entrepreneurship, Management and the Structure of Payoffs, 39-40, 252-3.

${ }^{6}$ Tatsos, Shadow Economy, 293.

${ }^{7}$ See Revenue Statistics, OECD.stat, $<$ https://stats.oecd.org/Index.aspx?DataSetCode=REV\# $>$

${ }^{8}$ Tatsos, Shadow Economy, 290, 223.

${ }^{9}$ Psalidopoulos, History of the Bank of Greece, 274.

${ }^{10}$ Kazakos, Between State and Market, 396.

${ }^{11}$ Milios, 'The Greek Economy', p. 18.

${ }^{12}$ Long-term Statistical Series of the Greek Economy, 10.

${ }^{13}$ Kazakos, Between State and Market, 389.

${ }^{14}$ The study covered 11 European Union Member States, four candidate countries, one applicant country and one country that is neither a candidate nor an applicant.

${ }^{15}$ European Commission, Helping Firms Grow, 136-7.

${ }^{16}$ Kipping and Üsdiken, 'History in Organization and Management Theory', 542-3.

${ }^{17}$ Braunerhjelm and Henrekson, 'Entrepreneurship, institutions, and economic dynamism', 108

${ }^{18}$ Baumol, 'Entrepreneurship: Productive, Unproductive, and Destructive', 917.

${ }^{19}$ See North, Institutions, Institutional Change and Economic Performance; Acemoglu and Robinson, Why Nations Fail, 2012.

${ }^{20}$ For more recent works on the impact of institutions on entrepreneurship see, for example, Welter and Gartner, A Research Agenda for Entrepreneurship and Context and Randolph, Tasto and Salvino, Public Policy, Productive and Unproductive Entrepreneurship.

${ }^{21}$ Baumol, 'Entrepreneurship: Productive, Unproductive, and Destructive', 895. Baumol puts forward the same argument in subsequent works too, such as, for example, in The Microtheory of Innovative Entrepreneurship.

${ }^{22}$ Schumpeter, in Baumol, 'Entrepreneurship: Productive, Unproductive, and Destructive', 896-7.

${ }^{23}$ Ibid., 897.

${ }^{24}$ Baumol, 'Formal Entrepreneurship Theory in Economics', 203.

${ }^{25}$ Ibid., 'Entrepreneurship: Productive, Unproductive, and Destructive', 915.

${ }^{26}$ Ibid., Entrepreneurship, Management, and the Structure of Payoffs, 9-10.

${ }^{27}$ Baumol, Litan and Schramm, Good Capitalism, Bad Capitalism.

${ }^{28}$ Baumol, 'The Entrepreneur in History'. (in the invention of enterprise, apo sel ix-xiv).

${ }^{29}$ Douhan and Henrekson, 'The Political Economy of Entrepreneurship', 20.

${ }^{30}$ Henrekson, 'Entrepreneurship and Institutions', 17.

${ }^{31}$ Ibid., 19. There have been of course, works focusing solely on tax rates and the level of taxes, such as, for example, Domar and Musgrave as well as Sinn, which concluded that under the assumption of risk aversion higher taxes encourage risk taking and therefore also entrepreneurship (Douhan and Henrekson, 21). There have also been a number of empirical literature contributions on the effects of taxation on small business creation. For example, the studies of Cullen and Gordon as well as Bruce and Mohsin, which show a 'weak negative relation' between tax levels and self-employment (Ibid.). Moreover, there is little distinction in the literature between the level of taxation and the methods of tax collection and enforcement. Estrin, Meyer and Bytchkova mention two early-2000s studies following such a distinction, based on survey data from transitional EU economies. The first one, by Aidis and Mickiewicz, suggests that '[t]he measure of taxation is correlated with two omitted variables, "frequent changes to tax policy" and "ambiguity of taxes", suggesting that all aspects of the system of corporate taxation, rather than the level alone, may inhibit entrepreneurial growth'. 
Also, Meyer et al's 2005 study indicates that unstable rules and regulation, 'rather than the actual state of these variables', are considered by foreign investors as a 'major obstacle'. Estrin, Meyer and Bytchkova, 'Entrepreneurship in Transition Economies', 705.

${ }^{32}$ Larroulet and Couyoumdjian, 'Entrepreneurship and Growth', 91.

${ }^{33}$ Edmark and Gordon, 'The choice of organizational form'.

${ }^{34}$ Sobel, 'Testing Baumol', 652. It should be noted here that Sobel's analysis has been criticized for identifying self employment with productive entrepreneurship (see Larroulet and Couyoumdjian, 93).

${ }^{35}$ Coyne and Leeson, 'The plight of underdeveloped countries', 244.

${ }^{36}$ Ibid.

${ }^{37}$ Jones and Wadhwani, 'Schumpeter's Plea: Rediscovering History', 22.

${ }^{38}$ Ibid., 13.

${ }^{39}$ Ibid., 27.

${ }^{40}$ Friedman and Jones, 'Business History': Time for Debate, 3.

${ }^{41}$ For example, in her study about business groups in Argentina, Barbero utilised Baumol's distinction between innovative, imitative, unproductive and rent-seeking entrepreneurship (Barbero, 'Business Groups in Argentina', 72, 88). Similarly, when analysing the determinants of entrepreneurial success in Italy, Toninelli, Vasta and Zavaronne mentioned Baumol's further distinctions between innovative and replicative entrepreneurs as well as the redistributive and productive ones (Toninelli, Vasta and Zavaronne, 'Explaining Entrepreneurial Success', 93-4). In a recent overview about the dimensions of business history research, Amatori stressed Baumol's point about the entrepreneur being 'one of the most intriguing characters of the economic scene' (Amatori, 'Business History', 26-7). Similarly, in their study about the relationship between innovation and competition policies in 1950s Britain, Broadberry and Crafts mentioned Baumol's contributions on the study of cartels and their welfare implications (Broadberry and Crafts, 'Competition and Innovation', 5,17). In a much older article concerning the study of entrepreneurship by business historians, Tony Corley analysed how business and corporate historians have utilised Baumol's theory on contestable markets (Corley, 'Firms and Markets', 62-3).

${ }^{42}$ Ortiz-Villlajos and Sotoka, 'An approach to entrepreneurial success'.

${ }^{43}$ Ibid., 144, 163.

${ }^{44}$ Giouras and Psalidopoulos, Occupation, Nazism and Greek Economy, 19-20; 34; 224-46.

${ }^{45}$ Tatsos, Shadow Economy, 287.

${ }^{46}$ Kalyvianakis et al., Tax regime, Shadow Economy and Tax Evasion in Greece, 275-9.

${ }^{47}$ Dertilis, Ineffectual of Effective? Taxes and Power in the Neo-hellenic State, 40.

${ }^{48}$ Ibid., pp. 26; 48-9.

${ }^{49}$ Tatsos, Shadow Economy, 295-7.

${ }^{50}$ Ibid., 299-300.

${ }^{51}$ Bank of Greece Governor's Annual Report for 1980, 18.

${ }^{52}$ Proposals of the Disincentives Committee, 3.

${ }^{53}$ Ibid.

${ }^{54}$ Ibid., 227-32

${ }^{55}$ Ibid., 163-224.

${ }^{56}$ CHROTEX Archive, 'Tax Courts', 6.

${ }^{57}$ Ibid.

${ }^{58}$ OEEC stands for the Organisation for European Economic Co-operation, renamed to Organisation for Economic Co-operation and Developmen (OECD) in 1961. 
${ }^{59}$ Vovolini Archives, Viomichaniki Epitheorissis, Vol. 26, Proceedings of the 2nd Congress of the Chambers of Commerce and Industry of Greece, 20-23.10.1957, 53-4. The full report was published in the newspaper $O$ EconomicosTahidromos ( 10 October 1957).

${ }^{60} \mathrm{He}$ was probably referring to legislation that was adopted for the promotion of investment.

${ }^{61}$ Bulletin of the Chamber of Commerce and Industry of Athens, 1 January 1965, 16.

${ }^{62}$ Bulletin of the FGI, 17, 195, 15 August 1970, 1.

${ }^{63}$ Ibid.

${ }^{64}$ Bulletin of the Chamber of Commerce and Industry of Athens, August-September 1967, 89, p.457.

${ }^{65}$ Theodoros Staikos, 'The Problem of Tax Audits', The Tax Review, February 1972, 277, pp.81-2.

${ }^{66}$ Bulletin of the Chamber of Commerce and Industry of Athens, July-August 1977, 7-8, 4950 .

${ }^{67}$ Apart from being involved in business, Argyros has also served as a member of the European Parliament, the vice-President of UNICE, a member of the Executive Committee of the Trilateral Commission, the President of the World Textile Institute and the President of the Board of Directors of the Federation of Greek Industrialists; 'Stockwatch', Stelios Argyros; http://www.stockwatch.com.cy/nqcontent.cfm?a_name=bod_view\&bodn_id=5747\&lang=en and http://mba.aegean.gr/attachments/article/87/ArgyrosSteliosCV.pdf.

${ }^{68}$ Argyros, interview excerpt.

${ }^{69}$ See Baumol, 'Entrepreneurship: Productive, Unproductive and Destructive'.

${ }^{70}$ Union of Corporations and Limited Liability Companies, Board Meeting Minutes 24 April 1980, 135-6.

${ }^{71}$ Zolotas, Our Economic Problem - A TV discussion, 8.

${ }^{72}$ Photopoulos, 'The Administration of the Greek Tax System', 896.

${ }^{73}$ Kazakos, Between State and Market, 269-70.

${ }^{74}$ See, for example, Agapitos, Income Taxation in Greece, 47.

${ }^{75}$ Mpakoyiannis, 'Vassal' Taxpayers and the 'Sultan-like' System of the Tax Services', 6.

${ }^{76}$ Bulletin of the Chamber of Commerce and Industry of Athens, July-August 1977, 7-8, 49 50 .

${ }^{77}$ Union of Corporations and Limited Liability Companies, Board Meeting Minutes

24.4.1980, 135-6.

${ }^{78}$ Bulletin of the Chamber of Commerce and Industry of Athens, February 1977, 2, 10.

${ }^{79}$ Demathas, 'Greek Economy and European Community', 22.

${ }^{80}$ Ibid.

81 'In the labyrinth of the VAT return', I Kathimerini, 3.3.1988, 9.

${ }^{82}$ Vovolini Archives, Viomichaniki Epitheorissis, Vol. 26, Proceedings of the 2nd Congress of the Chambers of Commerce and Industry of Greece, 20-23 October 1957, speech of A.

Nikolopoulos, president of the Athens Traders Association, 73.

${ }^{83}$ The 'Konstantinos G. Karamanlis' Foundation, 'Historical Archive', Konstantinos Papakonstantinou; http://www.ikk.gr/Default.aspx?tabid=236 .

${ }^{84}$ No further information about such Advisory Committees has been found, with regards, for example, to their composition.

${ }^{85}$ The 'Konstantinos G. Karamanlis' Foundation, 'Konstantinos Papakonstantinou Archive', File 202A, Findings of the Economics Committee, 1959-1961, Notes on Tax Evasion, Measures against tax theft, 4.

${ }^{86}$ Vovolini Archive, Viomichaniki Epitheorissis, Vol. 26, 1959, Proceedings of the 2nd Congress of the Chambers of Commerce and Industry of Greece, 20-23 October 1957, 268-9. 
${ }^{87}$ Vovolini Archive, Viomichaniki Epitheorissis, Vol. 32, 1965, Proceedings of the 5th Congress of the Chambers of Commerce and Industry of Greece - 8th theme of the agenda, 14-17 June 1964, 171.

${ }^{88}$ Bulletin of the Chamber of Commerce and Industry of Athens, May 1981, 5, 3.

${ }^{89}$ This was introduced through a relevant circular in 1976 (see I Kathimerini, 29 May 1976, 11).

${ }^{90}$ Union of Corporations and Limited Liability Companies, Board Meeting Minutes 8 October 1975, 130.

${ }^{91}$ Ibid., 130-1.

${ }^{92}$ Bulletin of the Chamber of Commerce and Industry of Athens, October 1988, 10, 3;16.

${ }^{93}$ Bulletin of the FGI, October-November 1988, 504, 7.

${ }^{94}$ The 'Konstantinos G. Karamanlis' Foundation, Konstantinos Papakonstantinou Archive, File 202A', Findings of the Economics Committee, 1959-1961, Notes on Tax Evasion, Measures against tax theft, 9 .

${ }^{95}$ Examples of such cases can be found here: I Kathimerini, 17 September 1976, 8; I Kathimerini, 6 October 1979, 4; I Kathimerini, 28August 1980, 3; Ta Nea, 27 February 1978, 16; Ta Nea, 13 December 1978, 16.

${ }^{96}$ Argyros, interview excerpt.

${ }^{97}$ In later periods, instead of 'commando' the equally unfortunate 'rambo' nickname was used to describe such groups (see for example I Kathimerini, 8.November 2006, http://www.kathimerini.gr/267986/article/oikonomia/ellhnikh-oikonomia/elegxoi-seepixeirhseis-me-laptop-eformoyn-oi-rampo-ths-eforias).

${ }^{98}$ Bulletin of the Chamber of Commerce and Industry of Athens, September 1978, 9, 27.

${ }^{99}$ Ibid., May 1981, 4, 3.

${ }^{100}$ Retired tax officer requesting anonymity, interview data.

${ }^{101}$ For the 1980s, see indicatively: Rizospastis, 7 August 1982, 6; Ta Nea, 7 August 1982, 12; Ta Nea, 29 December 1981, 1; Ta Nea, 23 December 1981, 1; Ta Nea, 24 November 1983, 1; I Kathimerini, 7 September 1983, 3; I Kathimerini, 15 June 1986, 2; I Kathimerini, 21 May 1987, 14; I Kathimerini, 11 September 1987, 8; I Kathimerini, 7 September 1988, 16. 